\title{
Penerapan Healing Architecture dengan Konsep Slow Living dalam Perancangan Ruang Publik Pereda Stres
}

\author{
Adinda Aprilia Kirana Ruspandi dan Angger Sukma Mahendra \\ Departemen Arsitektur, Fakultas Arsitektur, Desain dan Perencanaan, Institut Teknologi Sepuluh Nopember (ITS) \\ e-mail: angger@arch.its.ac.id
}

\begin{abstract}
Abstrak-Fast Paced Life atau biasa disebut dengan hidup-serbacepat adalah gaya hidup dengan aktivitas padat dan terus menerus. Fast Paced Life dapat mendorong stimulasi berlebih dan overscheduling, yang menjadi stres kronis yang menyebabkan emosi dan kebiasaan yang tidak stabil. Usulan objek disain adalah ruang publik yang dapat meredakan stress masyarakat Serpong akibat fast paced life. Peranan bangunan ruang publik adalah membantu penyembuhan dari sisi psikologis atau pengobatan non medis yang menggunakan pendekatan prinsip-prinsip desain yang diterapkan pada objek. Fungsi bangunan sebagai ruang publik pereda stres akibat fast paced life maka diterapkan pendekatan healing architecture dan slow living pada obyek desain. Healing architecture merupakan sebuah pendekatan dimana tujuan utama dari penggunaanya adalah untuk membantu menyembuhkan pengguna dengan konsep pembentukkan lingkungan perawatan yang memadukan aspek fisik serta psikologis pasien di dalamnya yang bertujuan untuk mempercepat proses penyembuhan. Sedangkan slow living merupakan sebuah gaya hidup yang dengan tempo lambat dan lebih mengutamakan kualitas waktu. Gaya hidup tersebut bertolak belakang dengan gaya hidup fast paced life. Obyek desain menggunakan pola lingkaran sebagai acuan dalam proses mendesain. Sebuah eksperimen menunjukkan bahwa curve atau melengkung dapat memperlambat tempo kecepatan manusia saat berjalan. Oleh karena itu lingkaran dipilih menjadi pola acuan saat mendesain karena semua sisi lingkaran merupakan curve atau melengkung. Obyek desain akan menggabungkan karakteristik mall (community mall) dan ruang publik. Community mall terdiri dari beberapa massa bangunan yang dihubungkan dengan jalan setapak. Karakteristik ini lah yang akan diterapkan pada obyek desain.
\end{abstract}

Kata Kunci-Fast Paced Life, Healing Architecture, Ruang Publik.

\section{PENDAHULUAN}

G LOBALISASI menjadi salah satu faktor utama orang Jorang di kota besar memiliki gaya hidup serba cepat. Dan pada era globalisasi ini muncul ungkapan "waktu adalah uang". Orang yang salah mengartikan ungkapan tersebut akan benar benar mengagung-agungkan waktu. Mereka tidak mau menghabiskan waktu mereka pada kegiatan yang menurut mereka tidak penting.

Fast paced life merupakan sebuah istilah dalam bahasa inggris yang berarti hidup serba cepat atau hidup dengan tempo cepat. Istilah ini biasa digunakan dalam gaya hidup masyarakat urban yang selalu menuntut untuk melakukan kegiatan dengan cepat. Fast Paced Life atau biasa disebut dengan hidup-serba-cepat

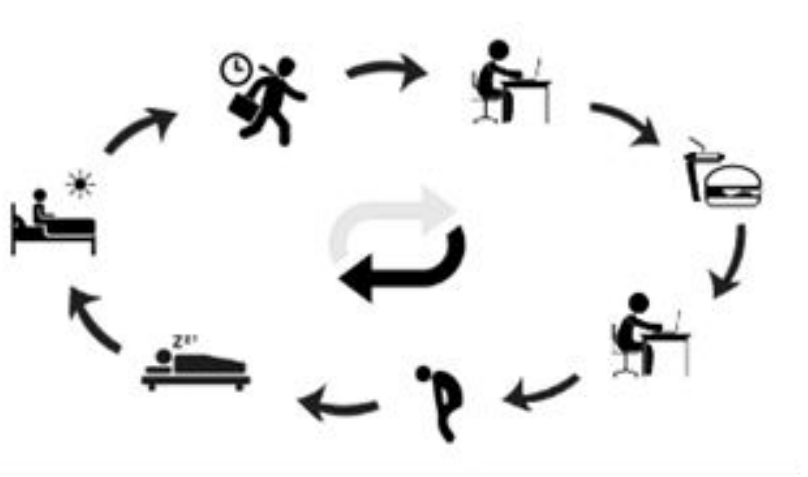

Gambar 1. Ilustrasi kegiatan orang dengan Fast Paced Life.

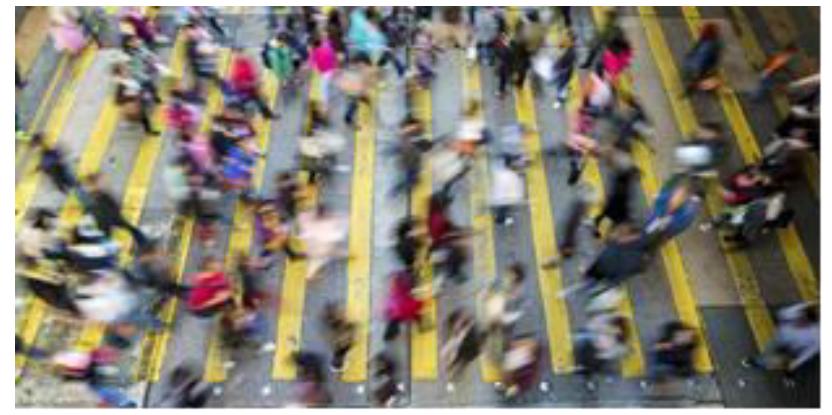

Gambar 2. Ilustrasi masyarakat urban.

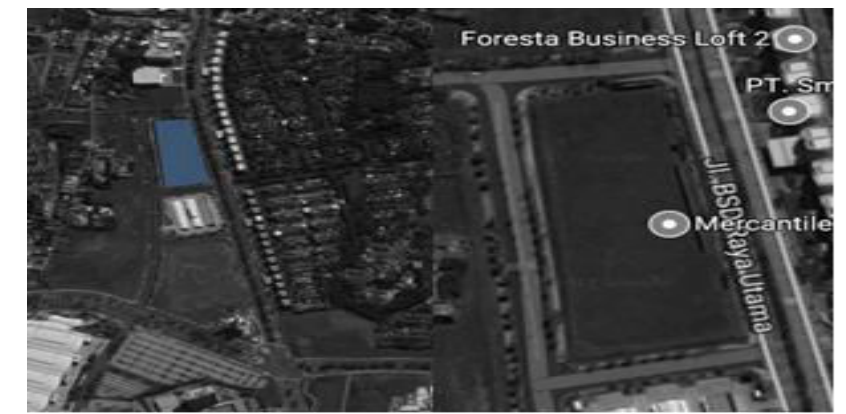

Gambar 3. Lokasi site obyek desain yang terletak di jalan BSD Raya Utama.

adalah gaya hidup dengan aktivitas padat dan terus menerus. Setelah melakukan suatu kegiatan langsung mengerjakann kegiatan lainnya tanpa henti (Gambar 1).

Fast Paced Life dapat mendorong stimulasi berlebih dan overscheduling, yang menjadi stres kronis yang menyebabkan emosi dan kebiasaan yang tidak stabil [1]. Menurut Ketua Umum Pengurus Pusat Perhimpunan Dokter Spesialis 
Tabel 1. Kriteria Healing Garden

\begin{tabular}{ll}
\hline \hline Feeling of security & Ketenangan \& \\
\hline $\begin{array}{l}\text { Different rooms } \\
\text { Privacy and social interaction }\end{array}$ & Privasi \\
$\begin{array}{l}\text { Understanding user groups and their } \\
\text { needs }\end{array}$ & $\begin{array}{l}\text { Sesuai Dengan } \\
\text { Offering different types of activities }\end{array}$ \\
$\begin{array}{l}\text { Basic characteristics for rest and activity } \\
\text { Surrounding and views }\end{array}$ & View \\
\hline \hline
\end{tabular}

Tabel 2.

Fasilitas penunjang aktivitas yang ada pada obyek desain

\begin{tabular}{|c|c|c|c|}
\hline $\begin{array}{c}\text { Cara } \\
\text { Menghilangk }\end{array}$ & \multicolumn{2}{|c|}{ Aktivitas yang Terjadi } & Fasilitas Arsitektural \\
\hline \multirow{5}{*}{ Slow Living } & Mindful & Meditasi & Health \& Beauty Center \\
\hline & Living & Yoga & Health \& Beauty Center \\
\hline & \multirow{2}{*}{ Slow Food } & Makan & Restaurant \\
\hline & & Market & Restaurant \\
\hline & Slow Book & $\begin{array}{l}\text { Membac } \\
\text { a buku }\end{array}$ & Book Store \\
\hline \multirow{11}{*}{$\begin{array}{l}\text { Menejemen } \\
\text { Stres }\end{array}$} & \multicolumn{2}{|l|}{ Jalan jalan } & Park \\
\hline & \multicolumn{2}{|c|}{ Meluangkan waktu di alam } & Park \\
\hline & \multicolumn{2}{|c|}{ Berinteraksi dengan teman } & Everywhere \\
\hline & \multicolumn{2}{|c|}{ Olahraga } & Health \& Beauty Center \\
\hline & \multicolumn{2}{|c|}{ Berendam } & Health \& Beauty Center \\
\hline & \multicolumn{2}{|c|}{ Menyalakan lilin beraroma } & Health \& Beauty Center \\
\hline & \multicolumn{2}{|c|}{$\begin{array}{l}\text { Menikmati secangkir kopi } \\
\text { atau teh }\end{array}$} & Coffee and Tea Shop \\
\hline & \multicolumn{2}{|c|}{ Massage } & Health \& Beauty Center \\
\hline & \multicolumn{2}{|c|}{ Membaca buku } & Book Store \\
\hline & \multirow{2}{*}{\multicolumn{2}{|c|}{ Mendengarkan musik }} & Amphitheatre \\
\hline & & & Amphitheatre \\
\hline
\end{tabular}

Kedokteran Jiwa Indonesia (PDSKJI) ini, lingkungan yang dinamis, gaya hidup kaum urban yang serba cepat, masalah pemanasan global, sebagian hal umum yang bisa memicu seseorang mengalami kecemasan (Gambar 2 dan 3).

\section{METODE}

\section{A. Healing Architecture}

Healing architecture merupakan sebuah pendekatan dimana tujuan utama dari penggunaanya adalah untuk membantu menyembuhkan pengguna, dimana penerapan healing environment merupakan salah satu konsep pembentukkan lingkungan perawatan yang memadukan aspek fisik serta psikologis pasien di dalamnya yang bertujuan untuk mempercepat proses penyembuhan [2].

Setelah pendekatan healing architecture dikaitkan dengan isu yang dibahas, maka ditentukan fungsi ruang publik yang sesuai dengan kebutuhan. Pendekatan healing architecture ini dapat diterapkan pada ruang luar atau lansekap bangunan yang akan di desain. Ruang luar tersebut tidak hanya berfungsi sebagai taman saja tetapi bisa menjadi media untuk menghilangkan stress. Dan seringkali penyebutan taman yang difungsikan sebagai pereda stres disebut healing garden.

\section{B. Healing Garden}

Ulrich (1999) mengusulkan istilah healing garden ini mengacu pada berbagai fitur taman yang memiliki kemampuan

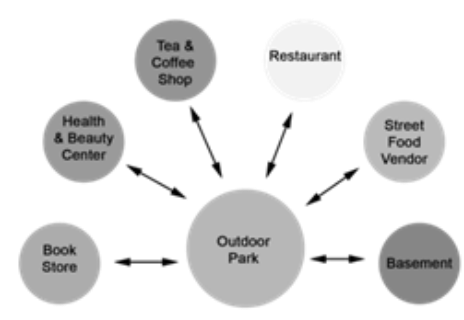

Gambar 4. Healing Garden.

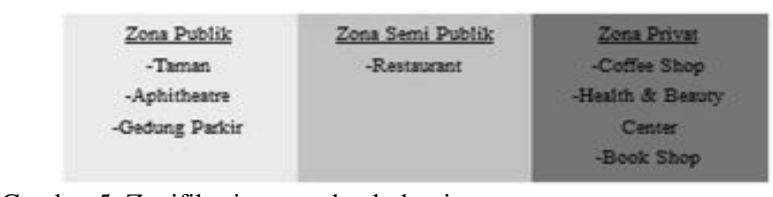

Gambar 5. Zonifikasi ruang obyek desain.

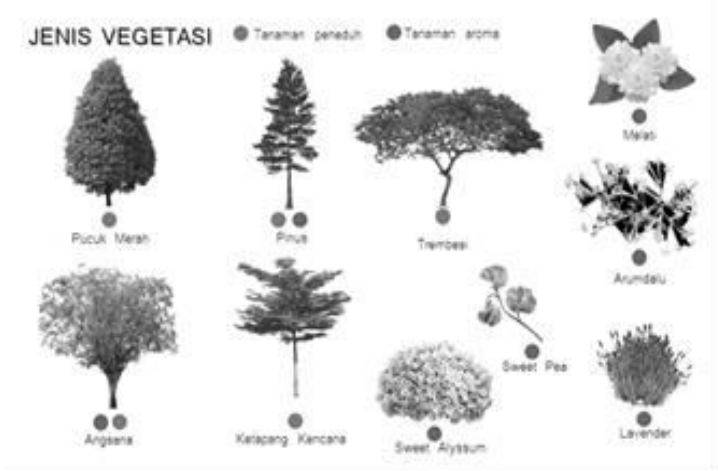

Gambar 6. Jenis vegetasi yang digunakan adalah tanaman peneduh dan tanaman aroma.

untuk mendorong restorasi dari stres dan juga memiliki efek positif lainnya pada pasien, staf dan pengunjung (Gambar 4).

Menurut Stigsdotter \& Grahn (2002) taman yang bersifat healing memiliki kriteria-kriteria tersendiri yang harus dicapai untuk dapat digunakan dan tepat sasaran [3]. (Tabel 1)

\section{Slow Living}

Slow living merupakan gaya hidup yang mengharuskan orang untuk melakukan suatu kegiatan dengan tempo kecepatan yang benar dan tidak terburu buru. Konsep gaya hidup ini akan menjadi pendekatan yang diterapkan pada bangunan. Isu yang terjadi adalah fast paced life atau hidup serba cepat yang menyebabkan berbagai masalah psikologis, maka penyelesaian untuk isu tersebut adalah dengan menerapkan konsep slow living atau hidup dengan tempo lambat (tidak terburu buru). Dengan harapan pengunjung atau user dapat menikmati "lambat", dan merasakan sedikit waktu luang sehingga bangunan tersebut berfungsi sebagai pereda stres (stress reliever) untuk pengguna (Tabel 2) [4].

Menurut sebuah komunitas Footprint Choice (www.slowmovement.com), slow movement terbagi menjadi 7 kategori yaitu:
1. Slow Living (mindful living)
2. Slow Cities
3. Slow Travel
4. Slow Food
5. Slow Schools
6. Slow Books
7. Slow Money 


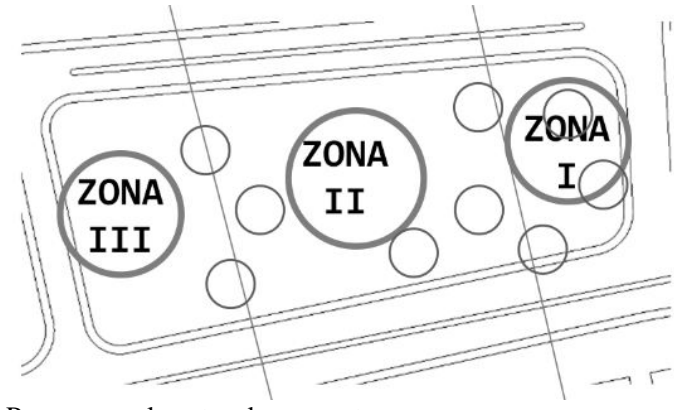

Gambar 7. Proses pemolaan tapak menurut zona.

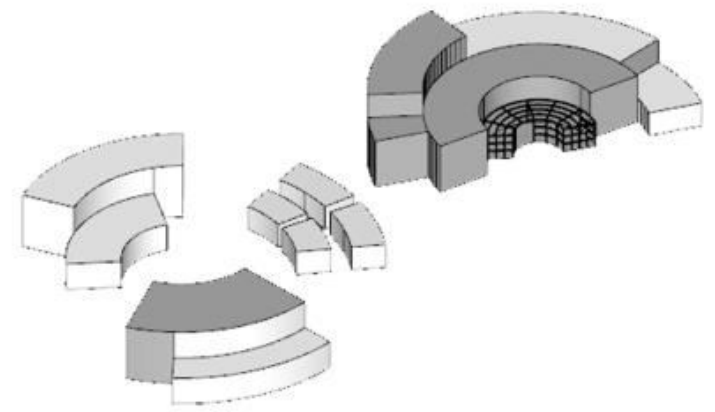

Gambar 8. Penataan massa bangunan.

Dari ketujuh kategori tersebut ada beberapa kategori yang dapat diterapkan kedalam desain bangunan. Mindful living, slow food dan slow books dirasa dapat diterapkan dalam konsep bangunan.

1. Slow Living (mindful living)

Mindful living adalah cara hidup yang mendorong orang untuk merasa tenang saat berhubungan dengan saat sekarang dan tidak melakukan kegiatan dengan tempo yang terlalu cepat.

\section{Slow Food}

Slow food muncul karena makanan cepat saji yang semakin banyak. Komponen penting dari gerakan Slow Food adalah untuk mengetahui tentang asal-usul dan rasa makanan. Ini bertujuan untuk menimbulkan apresiasi terhadap makanan dan kesenangan dalam memproses dan mengkonsumsi makanan.

3. Slow Books

Slow books adalah tentang mendapatkan kembali cinta membaca buku-buku. Ada banyak manfaat membaca secara teratur; pengurangan tingkat stres, peningkatan kreativitas, inspirasi dan motivasi, hiburan dan tawa yang baik, serta perspektif yang lebih luas dan pikiran yang lebih terbuka [5].

$\underline{\text { Aktivitas yang Dilakukan }}$

\section{Aktivitas Slow Living}

Slow food dapat diterapkan kedalam restoran dan kafe yang ada di dalam objek desain. Slow books dapat diterapkan pada ruang baca atau toko buku yang akan ada di dalam objek desain. Sedangkan mindful living akan diterapkan ke seluruh objek desain yang mana pengguna dapat merasakan "lambat", dan merasakan sedikit waktu luang diantara kehidupan yang serba cepat. Mindful living juga dapat diterapkan dengan cara kontemplasi atau yoga dengan begitu pengunjung dapat

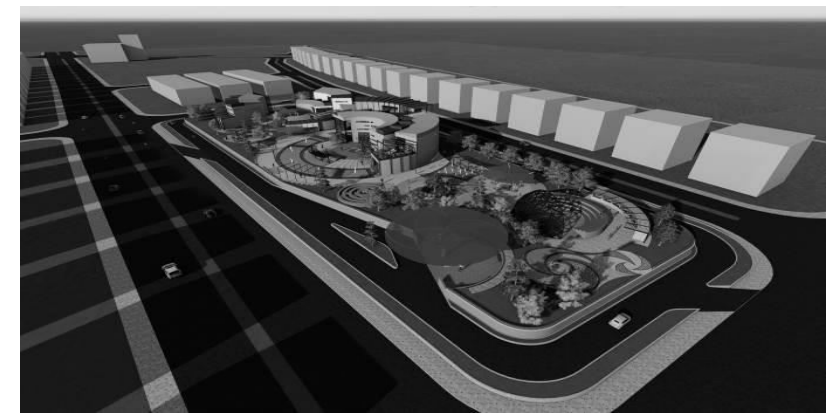

Gambar 9. Perspektif mata burung obyek desain.

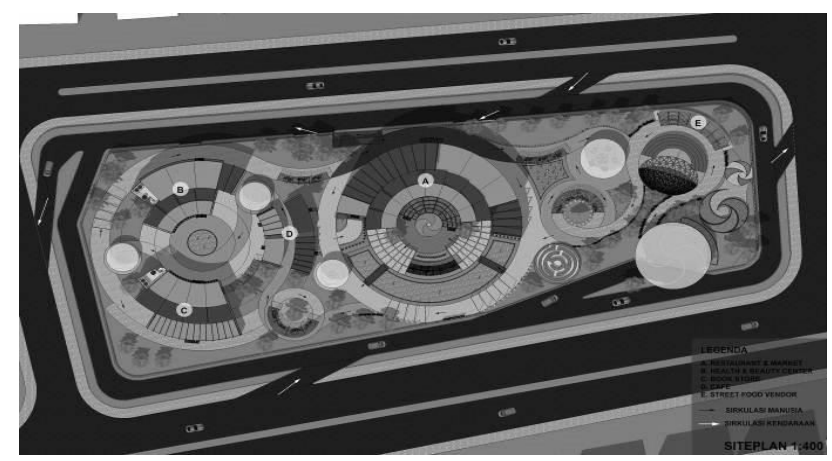

Gambar 10. Siteplan obyek desain.

menikmati waktu mereka dengan tenang dan menghilangkan stress (Gambar 6).

\section{Aktivitas Menejemen Stres}

Menejemen stres adalah tentang mengambil alih pemikiran, emosi, jadwal, lingkungan, dan cara menghadapi masalah yang menyebabkan stres. Ada banyak cara meluangkan waktu untuk bersenang senang dan relaksasi dengan berbagai macam aktivitas.

Aktivitas - aktivitas tersebut dapat dihadirkan pada bangunan dengan menyesuaikan aktivitas tersebut dengan fungsi bangunan. Dengan hadirnya aktivitas aktivitas tersebut pada obyek desain, diharapkan pengunjung dapat meredakan stres akibat fast paced life pada obyek desain (Gambar 7, 8, 9 dan 10).

\section{HASIL DAN EKSPLORASI}

Objek desain merupakan ruang publik tertutup (internal public space) yang memiliki fasilitas yang dapat menunjang masyarakat untuk meredakan stress akibat fast paced life. Obyek desain akan menggabungkan karakteristik mall (community mall) dan ruang publik. Community mall terdiri dari beberapa massa bangunan yang dihubungkan dengan jalan setapak. Karakteristik ini lah yang akan diterapkan pada obyek desain.

Proses dalam mendesain dimulai dari pembagian tapak menurut zona. Tapak dibagi menjadi 3 zona sesuai dengan tingkat kebisingan dan keramaian seperti berikut:

ZONA I : Zona Publik dengan tingkat kebisingan +++

ZONA II : Zona Semi Publik dengan tingkat kebisingan ++

ZONA III : Zona Private dengan tingkat kebisingan +

Lingkaran sebagai bentuk dasar pemolaan pada tapak. Pola lingkaran diletakkan di ketiga zona dengan sumbu yang sejajar. Pola lingkaran kecil diletakkan di spot spot tertentu 


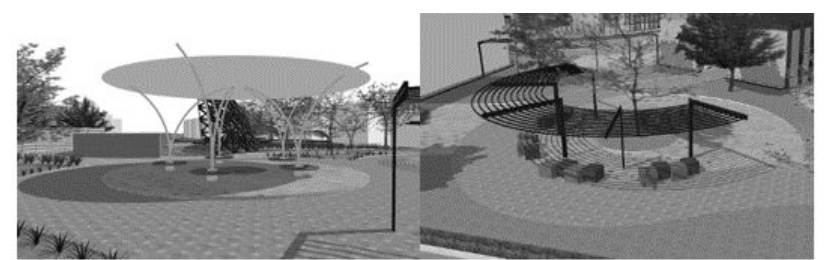

Gambar 11. Kriteria ketenangan \& privasi dalam penerapan Healing Architecture.

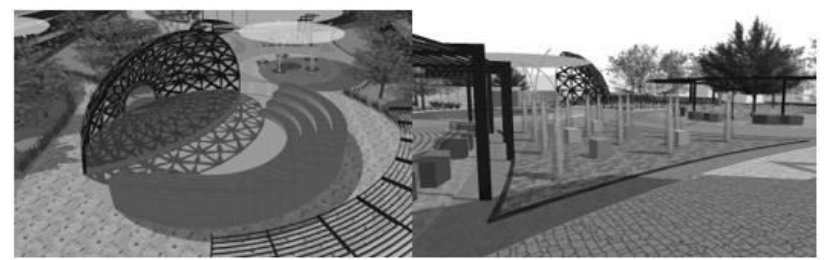

Gambar 12. Kriteria sesuai dengan kebutuhan penggunan dalam penerapan Healing Architecture.

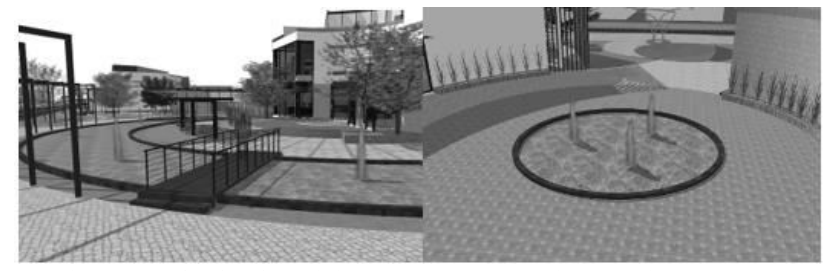

Gambar 13. Kriteria view dalam penerapan Healing Architecture.

yang digunakan untuk menentukan spot buffer pada ruang luar. Sedangkan untuk penataan massa bangunan berdasarkan zonifikasi ruang. Dari publik hingga privat.

Jalur sirkulasi berbentuk curve karena curve memperlambat kecepatan manusia saat berjalan. Lebar walkways bervariasi antara 3 meter sampai 5 meter. Jalan yang lebar juga membuat pengguna memperlambat tempo berjalan mereka dibanding dengan jalan yang sempit.

Penerapan Healing Architecture

1. Ketenangan \& Privasi

Shelter yang tersebar di berbagai titik dapat digunakan oleh pengguna untuk sekedar duduk atau berbincang, shelter tersebut dapat memberikan efek privasi pagi pengguna.

Jalan setapak dengan naungan serta tanaman disepanjang jalan akan memberikan efek ketenangan bagi pengguna. Tanaman serta naungan juga berperan sebagai pembatas sebuah ruang yang akan memberikan efek privasi untuk pengguna. (Gambar 11)

2. Sesuai Dengan Kebutuhan Pengguna

Aphitheatre dapat digunakan sebagai tempat pertunjukan musik dan teater. Tidak sebatas tempat pertunjukan musik dan teater tetapi amphitheatre dapat digunakan berbagai kegiatan sesuai kebutuhan.

Splash fountains merupakan sebuah water park dengan ketinggian air yang hanya mencapai mata kaki. Fitur ini dapat digunakan untuk semua umur dan cukup populer dikalangan masyarakat urban saat musim panas. (Gambar 12)

3. View

Kolam dengan jembatan pada taman akan menambah estetika pada taman tersebut. Komponen air lainnya seperti water fountain juga menambah estetika dan efek ketenangan untuk pengguna. (Gambar 13)

Penerapan Slow Living

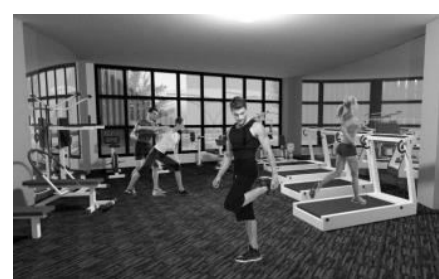

Gambar 14. Visualisasi Health \& Beauty Center

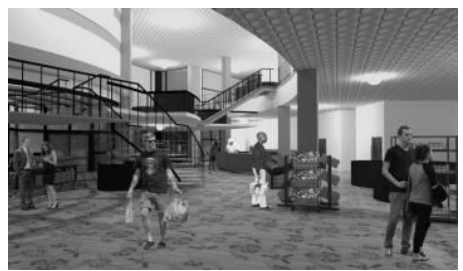

Gambar 15. Visualisasi Restaurant \& Market.

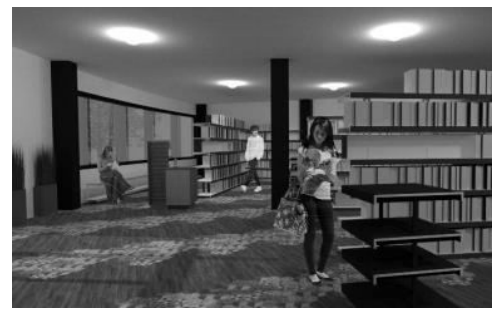

Gambar 16. Visualisasi Book Store.

\section{Mindful Living}

Health \& Beauty Center yang menggabungkan yoga studio, gym, spa \& massage dapat memberikan fasilitas relaksasi dan kontemplasi untuk pengguna. (Gambar 14)

\section{Slow Food}

Restaurant pada obyek desain akan digabungkan dengan pasar. Pengguna dapat memilih bahan makanan sesuai dengan keinginan mereka yang kemudian diolah menjadi sebuah hidangan. (Gambar 15)

\section{Slow Book}

Toko buku dengan area membaca yang nyaman untuk meningkatkan minat baca pengguna. Pengguna dapat membeli buku dan kemudian menuju area membaca dan menghabiskan waktu sambil membaca buku. (Gambar 16)

\section{KESIMPULAN}

Fast Paced Life atau biasa disebut dengan hidup-serba-cepat adalah gaya hidup dengan aktivitas padat dan terus menerus. Fast Paced Life dapat mendorong stimulasi berlebih dan overscheduling, yang menjadi stres kronis yang menyebabkan emosi dan kebiasaan yang tidak stabil.

Oleh karena itu tempat untuk menghilangkan dampak psikologis dari Fast Paced Life sangat diperlukan. Sebuah bangunan dengan konsep slow living didalamnya dirasa cukup efisien untuk mewadahi orang orang dengan gaya hidup fast paced life.

Aktivitas yang dapat dilakukan di obyek desain tersebut dibagi menjadi 2 kategori menghilangkan stres yaitu dengan slow living dan menejemen stres. Dengan hadirnya aktivitas aktivitas tersebut pada obyek desain, diharapkan pengunjung dapat meredakan stres akibat fast paced life pada obyek desain. 


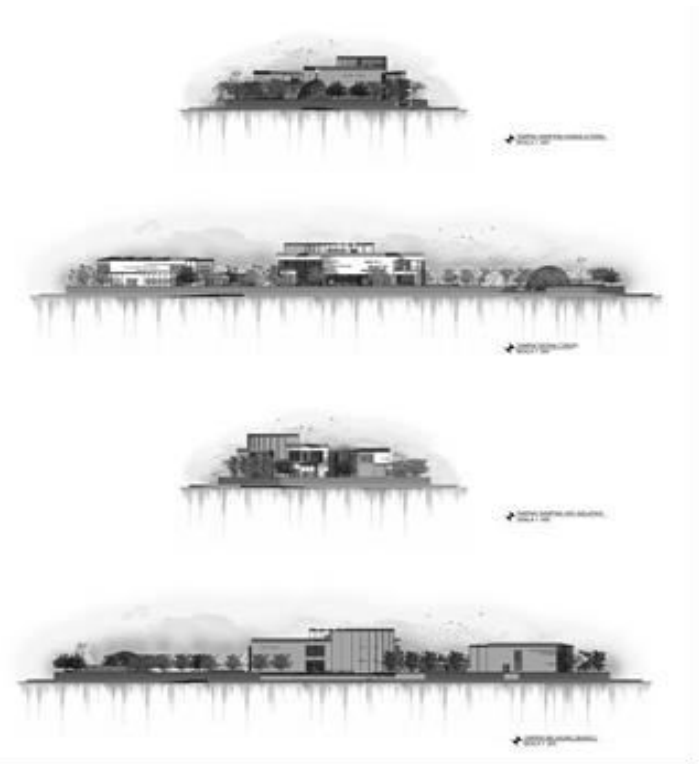

Gambar 17. Tampak bangunan.
Pendekatan yang digunakan dalam obyek desain ini adalah Healing Architecture dan Slow Living. Healing architecture berfungsi untuk membantu penyembuhkan pengguna baik secara fisik maupun psikologis. Sedangkan slow living merupakan sebuah gaya hidup yang dengan tempo lambat dan lebih mengutamakan kualitas waktu. Gaya hidup tersebut bertolak belakang dengan gaya hidup fast paced life.

\section{DAFTAR PUSTAKA}

[1] Anonymous, "Fast Pace Lifestyle = Health Crisis," 2014. [Online]. Available: http://www.rayur.com/fast-pace-lifestyle-healthcrisis.html. [Accessed: 03-Oct-2017].

[2] J. Murphy, "The Healing Environment," 2008. [Online]. Available: http://arch.ttu.edu. [Accessed: 16-Oct-2017].

[3] A. Shahrad, "What are the Design Principles of Healing Gardens." Alnarp, 2012.

[4] W. Parkins and G. Craig, Slow Living. New York: Berg Publishers, 2006.

[5] F. Choices, "Slow Movement," 2017. [Online]. Available: http://www.slowmovement.com. [Accessed: 18-Oct-2017]. 